Jurnal IImiah Iqra'

2541-2108 [Online] 1693-5705 [Print]

Tersedia online di: http://journal.iain-manado.ac.id/index.php/JII

\title{
Deradikalisasi Paham Keagamaan Melalui Pendekatan Pendidikan Agama Islam dalam Keluarga
}

\author{
Abdullah Botma \\ IAIN Parepare, Parepare, Indonesia \\ abdullahb@iain-parepare.ac.id
}

\begin{abstract}
Abstrak
Maraknya gerakan-gerakan radikalisme dan terorisme yang mengancam keutuhan NKRI telah menjadi perhatian serius pemerintah, dunia pendidikan dan juga lembaga-lembaga pemerhati semangat kebangsaan. Berbagai upaya telah dilakukan dalam rangka menangkal dan menanggulangi gerakan tersebut salah satunya dengan menambah materi anti radikalisme pada kurikulum pembelajaran di sekolahsekolah. Tulisan ini mengemukakan gagasan untuk menangkal gerakan dan laju radikalisme melalui pendidikan agama Islam yang diberikan oleh orang tua dalam keluarga. Hal ini dipandang akan sangat berpengaruh dikarenakan keluarga merupakan sekolah pertama tempat seorang anak ditempa dan dibentuk sehingga bisa meng-counter informasi dengan konsep dasar yang telah ditanamkan dalam pendidikan yang diperolehnya dalam keluarga. Melalui analisis kualitatif deskriptif, tulisan yang menggunakan metode library research ini menemukan bahwa perlunya pendidikan agama Islam diajarkan dalam bentuk teori dan praktik dalam keluarga adalah salah satu gerakan deradikalisasi yang mesti mendapat perhatian dan disosialisasikan kepada masyarakat.
\end{abstract}

Kata kunci: Deradikalisasi; Pendidikan Agama; Keluarga.

\begin{abstract}
The rise of radicalism and terrorism movements that threaten the integrity of the Republic of Indonesia has become a serious concern of the government, the world of education and also institutions observing the spirit of nationality. Various efforts have been made in order to ward off and overcome this movement, one of which is by adding anti-radicalism material to the learning curriculum in schools. This paper proposes to counteract the movement and the pace of radicalism through Islamic
\end{abstract}


religious education provided by parents in the family. This is considered to be very influential because the family is the first school where a child is forged and formed so that it can counter information with the basic concepts that have been implanted in the education that he gets in the family. Through descriptive qualitative analysis, this writing using the library research method finds that the need for Islamic religious education to be taught in the form of theory and practice in the family is a de-radicalization movement that must receive attention and be socialized to the community.

Keywords: Deradicalization; Religious education; Family.

\section{Pendahuluan}

Pertengahan Maret 2019 lalu, dunia digemparkan dengan tindakan terorisme yang dilakukan oleh seorang yang teridentifikasi bernama Brandon Tarrant di Masjid al-Noor Christchurch, Selandia Baru. Brandon mengakui perbuatannya dan mengklaim bahwa serangan tersebut mewakili jutaan warga Eropa dan bangsabangsa neo-nasionalis yang lain. Kejadian tersebut menambah panjang daftar aksi terorisme sekaligus radikalisme yang membuat umat manusia memiliki pandanganpandangan khusus tersendiri terhadap agama.

Radikalisme atau terorisme laksana dua sisi mata uang koin yang saling bertolak tapi tak bisa dipisahkan. Kelompok radikal biasanya memanfaatkan isu-isu keagamaan dan konflik komunal di masyarakat untuk memobilisasi massa dalam melakukan aksi untuk berkonfrontasi baik pada negara maupun kelompok tertentu yang dianggap berseberangan dengan kelompoknya. Radikalisme yang berujung pada aksi terorisme menjadi masalah penting untuk menjadi perhatian, khususnya bagi umat Islam (Wahab, 2019). Meskipun pemerintah sudah menerbitkan berbagai macam kebijakan dalam bentuk peraturan dan undang-undang yang mengatur tata kehidupan beragama agar tidak terjadi deharmonisasi dalam masyarakat, namun sepertinya radikalisme atas nama agama tidak kunjung berhenti. Justru sebaliknya, kian hari kian bertambah berbagai bentuk penganiyaan, pembakaran, perobohan tempat ibadah, penodaan ajaran dan keyakinan agama, serta penghinaan terhadap keyakinan agama atau pemahaman ajaran orang lain.

Upaya-upaya yang telah dilakukan pemerintah selama ini boleh dikatakan berhasil. Buktinya dengan ditangkapnya banyak gembong teroris yangmenjadi otak dari tindakan radikal dan terorisme di Indonesia. Data yang diambil dari Densus 88 AT Polri, pada tahun 2012 tercatat sudah lebih dari 600 pelaku teror yang 
tertangkap. Namun, di sisi lain gerakan-gerakan radikal ini masih tumbuh subur di kalangan umat Islam terutama mereka yang menginginkan tegaknya syari'at Islam secara instan dan ekstrim. Deradikalisasi agama juga dilakukan pemerintah dengan menggandeng ormas-ormas keagamaan seperti NU, Muhammadiyah dan ormas lainnya yang mempunyai pemikiran keagamaan yang moderat dapat dianggap sebagai bagian dari metode mengurangi dampak dan gerakan radikalisasi di Indonesia.

Gagasan tentang deradikalisasi agama yang ditempuh sebagai salah satu cara penanggulangan terorisme dan radikalisme melalui cara represif, proses hukum, penangkapan, penyidangan hingga eksekusi dirasakan kurang efektif, karena cara tersebut kurang menyentuh pada akar permasalahan yang sesungguhnya. Cara represif dengan pendekatan militeristik seperti penangkapan bahkan penembakan pelaku teror merupakan langkah memotong aksi teror dari tengah yang dianggap oleh banyak pihak tidaklah begitu efektif. Para pelaku teror ternyata tidak henti melakukan gerakan kekerasan, bahkan menuai motif baru dalam melakukan aksinya yaitu membalaskan dendam saudaranya yang telah dieksekusi mati oleh aparat keamanan, teknis penahanan yang tidak sesuai dengan prosedur, serta berbagai jenis tindakan negara atas mereka yang diduga, dituduh, didakwa dan tertangkap menjadi teroris. Satu kekerasan memunculkan kekerasan baru. Berdasarkan hal tersebut kemudian dipandang perlu untuk mencari metode yang lain untuk menghentikan berbagai macam terorisme (Wahid \& Dkk, 2010).

Gerakan anti radikalisme kini telah banyak dilakukan oleh berbagai pihak. Diketahui ada tiga institusi yang sangat penting dalam perannya sebagai pelindung generasi muda. Pertama lembaga pendidikan; melalui peran lembaga pendidikan, guru/dosen dan sivitas akademika aktif dalam memperkuat wawasan kebangsaan, sikap moderat dan toleran pada generasi muda. Kedua, keluarga; melalui peran orang tua dan lingkungan keluarga dalam menanamkan cinta dan menebarkan kasih kepada generasi muda dan menjadikan keluarga sebagai unit teman yang bisa diajak berdiskusi. Ketiga, komunitas; melalui peran tokoh masyarakat di lingkungan masyarakat untuk menciptakan ruang-ruang kondusif bagi tercipta dan terjaganya perdamaian di kalangan generasi muda.

Dalam keluarga, mendidik anak membutuhkan keterampilan khusus yang didasari oleh pendidikan yang tinggi, apalagi kondisi sosial politik Indonesia saat ini sedang diguncang oleh gerakan-gerakan terorisme dan radikalisme yang mengancam keutuhan NKRI. Di samping itu, kondisi sosial politik yang terjadi saat 
ini menuntut lingkungan keluarga menjadi wajib untuk memberikan pengaruh yang sangat signifikan terkait merebaknya gerakan Islam radikal dan fundamental yang berusaha menggantikan falsafah Pancasila, dan gerakan-gerakan lainnya yang dikhawatirkan akan mampu merusak masa depan anak, keluarga dan negara.

Sebagaimana yang diungkapkan dalam sebuah hadits nabi Muhammad saw. bahwa "Semua anak yang dilahirkan dalam keadaan fitrah, ibu dan bapaknyalah yang menjadikan Yahudi atau Nashrani" (HR. Bukhori Muslim), menjadi isyarat jelas yang menegaskan bahwa pembentukan karakter atau pribadi anak berasal dari ibu dan bapaknya atau keluarga. Maka pendidikan agama Islam yang moderat oleh keluarga akan menjadi tameng utama dalam upaya menangkal aksi radikalisme, fundamentalisme atau terorisme. Berdasarkan hal tersebut, tulisan ini akan memaparkan terkait dengan pentingnya pendidikan agama Islam dalam keluarga sebagai upaya menangkal radikalisme. Keluarga yang juga merupakan pranata sosial terkecil dari sebuah masyarakat yang berperan sebagai sarana pendidikan awal bagi anak-anak dan generasi muda seharusnya juga mampu menangkal gerakan radikalisme sejak dini.

\section{Metode}

Penelitian ini menggunakan metode penelitian kualitatif deskriptif dengan jenis penelitian kepustakaan (library research). Penelitian ini dilakukan dengan mengamati situasi dan kondisi negara melalui analisis media serta kondisi sosial masyarakat terkait dengan radikalisme dan penanganannya di ranah keluarga. Penelitian ini menekankan pada proses-proses sosial yang terjadi dalam masyarakat Indonesia dengan teknis pengambilan datanya bersumber dari informasi media elektronik, media cetak maupun informasi-informasi dari media sosial. Penulis mengidentifikasi dan menganalisis ciri-ciri radikalisme atau fundamentalisme yang terjadi pada anak dan remaja, menelaah unsur dan sifat-sifat serta sabab musabab terjadinya radikalisme dalam masyarakat. Setelah terkumpul, data tersebut kemudian dianalisa dan diinterpretasikan sehingga menjadi sebuah tulisan yang bersumber dari fenomena yang berupa data sebagai bahan primer dan pengumpulan teks dan pustaka sebagai bahan sekunder. Teknik analisis data yang digunakan adalah metode induktif yang disajikan dalam bentuk deskriptif yang pada akhirnya diharapkan mampu memberikan pandangan komprehensif terhadap peran pendidikan agama Islam sebagai salah satu upaya menanggulangi gerakangerakan radikal. 


\section{Hasil dan Pembahasan}

Radikalisme adalah suatu paham yang menghendaki adanya perubahan atau pergantian sistem yang ada pada masyarakat sampai ke akar-akarnya, bahkan kalau perlu sah-sah saja menggunakan cara-cara kekerasan. Radikalisme menghendaki adanya perubahan secara total terhadap sebuah kondisi yang melingkupi semua aspek kehidupan masyarakat. Namun, perubahan bersifat terlalu revolusioner seringkali harus "memakan korban" sementara keberhasilannya tidak sebanding bahkan tidak terukur.

Gerakan deradikalisasi yang telah ada selama ini harus dievaluasi total. Dibutuhkan sebuah konsep baru agar kelak tidak ada lagi orang yang bisa dibujuk atau bahkan dicuci-otaknya untuk menjadi teroris. Gerakan ini harus digalakkan sejak dini melalui lembaga tempat generasi muda mendapatkan pendidikan awal yang biasa disebut keluarga.

\section{Pengertian Deradikalisasi}

Kata radikal berasal dari Bahasa Latin "radix" yang berarti akar,pangkal, bagian bawah, menyeluruh, atau habis-habisan, serta amat keras untuk menuntut perubahan. Dalam Bahasa Inggris, kata radical memiliki makna ekstrim, menyeluruh, revolusioner, fanatik, dan fundamental. Sedangkan kata radicalism artinya doktrin atau praktik penganut paham radikal atau paham ekstrim (Nuhrison, 2009).

Kata deradikalisasi, yang mendapat imbuhan "de" dan akhiran "sasi" diambil dari kata Bahasa Inggris "deradicalization" memiliki arti, "opposite, reverse, remove, reduce, get off" (kebalikan atau membalik), kemudian imbuhan akhiran yang dilekatkan pada kata "radikal" menjadi radicalize, akhiran "ize" yang berarti"cause to be or resemble, adopt or spread the manner of activity or the teaching of" (suatu sebab untuk menyerupai atau untuk menjadi, memakai atau penyebaran cara mengajari) sehingga dalam imbuhan "de"- kata tersebut tidak mengalami perubahan bentuk. Sedangkan akhiran "ize" menjadi "isasi", yang memberikan makna proses kepada kata tersebut atau upaya untuk menghilangkan radikalisme (Marwan \& P, 2019).

Secara terminologi, radikalisme merupakan sebuah tindakan politik yang mengancam dunia (Islam maupun non-Islam) sebagai sebuah gerakan politik keagamaan. Radikalisme bukanlah fenomena dalam dunia Islam saja, tetapi juga fenomena global yang melanda dunia. Orang-orang yang memiliki pandangan yang 
radikal menganggap bahwa kondisi dunia tidak sesuai dengan apa semestinya terjadi dan oleh karena itu harus dirombak (Qadir, 2015).

Dari pengertian-pengertian tersebut dapat diketahui bahwa radikalisme agama adalah paham atau aliran yang keras dalam suatu ajaran agama tertentu. Menurut aliran ini setiap permasalahan / persoalan harus disikapi dengan tegas dan keras, tidak setengah-setengah apalagi ragu-ragu dalam beridak demi tegaknya ajaran agama tesebut. Namun terkadang aliran ini dalam bertindak melebihi aturan yang ada atau bahkan menghalalkan cara untuk mencapai tujuan (Salim, 2017b). Sekalipun sebagai fenomena politik, kehadiran radikalisme yang mengarah pada kekerasan sistematik, kekerasan aktual maupun kekerasan simbolik tetaplah dianggap sebagai sesuatu yang mengancam dunia. Hal ini disebabkan karena memang karakteristik dari gerakan radikalisme Islam (Islamic Radicalism) adalah tidak pernah siap untuk bersedia mendialogkan dengan pihak lain apa yang menjadi gagasannya, tetapi justru memaksakan pendapat kepada pihak lain dengan segala cara bahkan cenderung memaksa untuk kemudian pendapatnya diterima.

Sedangkan deradikalisasi adalah keseluruhan upaya untuk menetralisir paham-paham radikal melalui pendekatan interdisipliner, seperti hukum, agama, psikologi, dan sosial-budaya. Deradikalisasi biasanya diwujudkan dalam bentuk program reorientasi motivasi, resosialisasi, re-edukasi, serta mengupayakan kesejahteraan sosial dan kesetaraan antar masyarakat lain baik bagi mereka yang pernah terlibat terorisme maupun bagi simpatisan, agar timbul rasa nasionalisme dan mau berpartisipasi dengan baik dan aktif sebagai Warga Negara Indonesia (WNI) (Golose, 2009).

\section{Pendidikan Agama dalam Keluarga}

Pendidikan secara etimologi berasal dari Bahasa Latin educare, yang artinya “memasukkan sesuatu”. Adapun secara terminologi, istilah pendidikan merupakan proses perubahan sikap atau perilaku seseorang maupun kelompok dalam rangka berusaha mendewasakan manusia melalui pengajaran, suatu proses, dan aktfitas mendidik (Darmadji, 2013).

Pendidikan dilaksanakan untuk membimbing dan mendidik seorang anak untuk menemukan dan mengembangkan potensi yang dimilikinya. Menunjuk redaksi hadis yang telah diungkapkan sebelumnya bahwa setiap anak dilahirkan atas fitrahnya (suci) tanpa dosa, dan apabila anak tersebut menjadi Yahudi atau Nasrani, dapat dipastikan itu dikarenakan oleh orang tuanya. Orang tua wajib mengenalkan 
kepada anaknya tentang suatu hal yang baik, mana yang semestinya dikerjakan dan mana yang semestinya ditinggalkan. Dengan begitu, anak tersebut dapat tumbuh dan berkembang dalam pendidikan yang baik dan benar.

Pendidikan dalam keluarga berperan penting dalam pembentukan karakter setiap anak. Termasuk pemahaman agama yang baik di dalam keluarga, juga berperan sentral. Namun, pemahaman agama yang seharusnya ditekankan lagi-lagi bukan hanya sekedar paham keagamaan yang bersifat normatif-formal (bersangkutan dengan ibadah) dan tekstual saja, namun juga pemahaman keagamaan yang bersifat kontekstual dan berimplikasi kepada perilaku sosial. Hal ini disebabkan karena seorang anak tidak hanya baik dalam sisi normatif-formal (ibadah) namun juga harus baik dalam sosial kemasyarakatan.

Tujuan diadakannya pendidikan agama dalam keluarga berangkat dari tujuan pendidikan Islam secara umum yakni untuk mencapai tujuan hidup muslim, yaitu menumbuhkan kesadaran manusia sebagai makhluk Allah swt agar hidup, tumbuh dan berkembang menjadi manusia yang berakhlak mulia dan beribadah kepada-Nya. Menurut Zakiyah Drajat, pendidikan agama dalam keluarga meliputi pendidikan akidah, ibadah serta akhlak (Daradjat, 2014)

\section{Pendidikan Akidah}

Pendidikan akidah berbicara mengenai keimanan kepada Tuhan. Secara etimologis, keimanan berasal dari kata dasar "iman" yang memiliki arti percaya dengan sepenuh hati. Sedangkan para ulama mendefinisikan iman tidak hanya percaya dalam hati, melainkan juga harus dikuatkan dengan mengucapkan keimanan tersebut dengan lisan dan melakukannya dengan segenap anggota tubuh (Mahmud \& Dkk, 2013).

\section{Pendidikan Ibadah}

Pendidikan ibadah dalam keluarga mencakup keseluruhan ibadah, baik ibadah khusus yang hubungannya langsung dengan Allah seperti shalat, puasa, zakat, haji) maupun ibadah umum yang hubungannya dengan manusia (muamalah). Akan tetapi, ibadah yang dimaksud di sini tidak hanya terbatas pada ibadah mahdhah dan semua turunannya seperti membaca al-Qur'an, berdzikir, berdo'a dan beristighfar, namun ibadah juga mencakup segala sesuatu yang disukai Allah dan diridhoi-Nya, baik berupa ucapan, perbuatan yang tampak maupun yang batin. 


\section{Pendidikan Akhlak}

Pendidikan tentang akhlakul karimah merupakan hal yang sangat penting untuk diperhatikan dalam pendidikan keluarga. Mendidik akhlak seorang anak dapat dilakukan dengan cara melatih si anak dan membiasakan melakukan hal-hal yang baik, bersikap hormat kepada kedua orang tua, bertingkah laku yang sopan baik dalam perilaku keseharian maupun dalam bertutur kata. Tantangannya adalah pendidikan akhlak tidak cukup hanya diajarkan secara teoritik, melainkan juga harus disertai dengan contoh-contoh kongkrit untuk dihayati maknanya dan diteladani.

Dalam mendidik anak, tentunya sebuah keluarga harus meningkatkan kapasitas intelektual baik suami ataupun istri. Dalam membangun rumah tangga termasuk dalam mendidik anak diperlukan SDM yang tinggi apalagi zaman yang sering disebut dengan "zaman milenial" ini banyak sekali problem kehidupan masyarakat yang beresiko merusak mental dan karakter generasi muda. Menjadi hal yang sangat penting untuk mengetahui dan memahami fungsi keluarga, mulai dari fungsi keagamaan, melindungi, cinta kasih, sosial budaya, sosialisasi dan pendidikan, ekonomi, serta pembinaan lingkungan. Fungsi-fungsi tersebut, jika betul-betul dimengerti atau dipahami dan dijalankan oleh seluruh orang tua, maka paham dan praktik radikalisme jelas akan sulit masuk pada keluarga dan mempengaruhi anakanak.

Pendidikan agama dalam keluarga sangat penting untuk diajarkan terutama yang relevan dengan konteks sosia. Ketika gerakan radikalisme dan terorisme yang mengusung jihad yang bersifat offensif, misalnya melalui suicide bombing, aksi teror dengan kekerasan dan aksi-aksi serupa lainnya, maka tentu harus dijelaskan atau diajarkan terlebih dahulu mengenai makna jihad secara tuntas. Pengertian jihad dalam arti moderat yakni bekerja keras untuk mencapai tujuan yang sangat baik terutama untuk kemaslahatan umat harus menjadi doktrin utama yang akan membentengi fikiran-fikiran radikal seorang anak. Karena hampir bisa dipastikan pemaknaan jihad tersebut telah sedikit demi sedikit dihapus dari materi pengajaran karena konotasinya yang telah disalah artikan. Namun, justru harus ada upaya yang memadai untuk memberikan penjelasan secara memadai terutama dalam lingkungan keluarga, harus ada orang tua yang bisa menjelaskan tentang makna jihad yang bernuansa rahmatan lil alamin. Oleh karenanya, para orang tua pun harus mempersiapkan diri secara memadai agar tidak mengajarkan Islam atau agama apapun sesuai dengan konsepsi kaum radikalis. 


\section{Mencegah Radikalisasi Melalui Pendidikan Agama dalam Keluarga}

Membenarkan kalimat bijaksana "lebih baik mencegah dari pada mengobati", proses deradikalisasi agama terhadap orang-orang yang sudah menerima doktrin sangatlah berbeda dengan proses radikalisasi. Radikalisasi agama relatif lebih mudah diterima daripada deradikalisasi karena biasanya dilakukan kepada orang yang minim penguasaan ilmu agama atau dengan kata lain basis ilmu agamanya kurang mendalam (Salim, 2017b). Oleh sebab itu, mereka cukup mudah untuk menerima ajaran yang bersinggungan dengan agama karena ada "ruang kosong" dalam pikiran dan hati mereka. Menurut ilmu psikologi, sebagian dari manusia memiliki kecenderungan pada hal-hal yang baru apalagi yang memberikan rasa keselamatan entah itu datang dari agama ataukah dari yang lainnya. Afilisasi keagamaan akan lebih mudah diterima daripada afilisasi politik atau bahkan afilisasi ekonomi terkait dengan iman atau keyakinan (Martha, 2002).

Masalah lain dari proses deradikaliasi agama adalah kegiatan ini seringkali dilakukan secara sporadis dengan hanya mengutamakan hal-hal yang bersifat formalitas dengan paradigma proyek penanggulangan terorisme. Hal ini mengakibatkan deradikalisasi menjadi tidak efektif melawan gerakan radikalisasi agama yang dilakukan secara intensif, sistematik, terencana dan disiplin. Apatah lagi gerakan radikalisasi agama dilakukan dengan menggunakan jargon ketulusan dan semangat keimanan bahwa hal tersebut dilakukan demi menegakkan kalimat tauhid demi mengesakan Tuhan serta demi penegakan syariat Islam yang akan dibalas dengan bidadari dan surga. Janji-janji surgawi yang memang mendapatkan pembenaran dari berbagai doktrin kitab suci dan teks-teks suci lainnya, sehingga mereka yang menjalani pendidikan atau training radikalisasi akan dengan semangat membara membela apa yang telah diperoleh selama pelatihan.

Masalah dalam proses deradikalisasi tersebut hendaknya menjadi bahan pertimbangan dan pemikiran para pihak yang bertanggung jawab dalam penanggulangan aksi radikalisme dan terorisme di Indonesia, termasuk pihak penyelenggara pendidikan, dikarenakan belakangan ini gerakan radikalisasi mengarah kepada kaum muda terutama pelajar kelas menengah atas dan mahasiswa. Memberangus radikalisme tidak cukup dengan hanya menangkap dan menggiring para pelaku teror ke meja pengadilan atau menakuti mereka dengan ancaman hukuman mati, deradikalisasi agama pun harus dilakukan lebih awal dan sedini mungkin oleh keluarga terutama kepada anak-anak yang belum mengalami 
radikalisasi agama agar benar-benar efektif dan menjadi salah satu solusi penanggulangan radikalisme dan terorisme.

Pihak keluarga, dalam hal ini ayah dan ibu harus meningkatkan arus komunikasi dan pendekatan-pendekatan terhadap anak secara persuasif dan memberikan pemahaman mengenai konsep Islam rahmatan lil 'alamin. Pendekatan secara psikologis juga sangat diperlukan untuk memberikan pengertian kepada anak oleh orang tua karena orang tualah yang mampu berkomunikasi dari hati ke hati terhadap anak sekaligus melakukan diskusi-diskusi dengan menyisipkan doktrinisasi mengenai bahaya radikalisme. Di samping itu, orang tua juga bertugas melakukan implementasi dan praktik moderat serta toleran yang diterapkan pada anak di lingkungan rumah, baik terhadap anggota keluarga maupun tetangga, mengawasi buku bacaan anak, mengamati situs dan channel yang digandrungi anakanak, dan secara aktif memberikan contoh-contoh sikap moderat dan tasamuh yang berkaitan dengan praktik keagamaan yang berbeda. Orang tua juga memberikan informasi mengenai praktik radikalisme yang membawa kepada praktik intoleransi, yang berdampak pada terpecah belahnya bangsa, memilihkan lembaga pendidikan yang bebas dari doktrin radikalisme dan memfilterisasi situs-situs serta chanel yang bisa mengarahkan pemikiran radikal pada anak.

Sebagaimana yang telah disinggung di atas bahwa anak ibarat "kertas kosong yang berwarna putih”. Mereka dilahirkan dalam keadaan yang fitrah. Yang mewarnai mereka pertama kali adalah orang tuanya; ayah dan ibunya. Masa depan anak sangat tergantung pada situasi rumahnya, maka tugas utama dari orang tua adalah menjamin keselamatan masa depan anak-anak mereka.

Hai orang-orang yang beriman, peliharalah dirimu dan keluargamu dari api neraka yang bahan bakarnya adalah manusia dan batu; penjaganya malaikat-malaikat yang kasar, keras, dan tidak mendurhakai Allah terhadap apa yang diperintahkan-Nya kepada mereka dan selalu mengerjakan apa yang diperintahkan.(Qs. al-Tahrim: 6).

Ayat di atas diserukan bukan untuk laki-laki atau perempuan saja, namun seruan di atas diperuntukkan untuk orang-orang yang beriman yang terdiri dari perempuan dan laki-laki. Dari sini sebuah relasi dibutuhkan untuk menjaga anakanak dan keluarga dari api neraka.

Selain ditegaskan dalam al-Qur'an dan hadis, urgensi peran keluarga dalam membentuk karakter anak juga disampaikan banyak pemikir muslim. Salah satunya adalah Ahmad bin Muhammad bin Ya'qub bin Miskawaih (320 H/ 932 M-412 H/1030 
M) yang mengatakan bahwa peran keluarga dan lingkungan sangat menentukan model karakter anak. Apabila hidup dalam lingkungan yang baik, seorang anak akan tumbuh menjadi pribadi yang baik. Tumbuh dalam lingkungan yang bermasalah, akan membuat sang anak senantiasa dirundungi masalah. Oleh sebab itu, pola asuh orang tua terhadap anak sangat penting untuk diperhatikan. Dalam ilmu sosiologi, hubungan orang tua-anak ini disebut "hubungan dalam" yang berlangsung terusmenerus tanpa batas, dan karenanya sangat membekas (Salim, 2017a).

Orang tua yang menerapkan gaya pengasuhan yang bersifat demokratispasti akan mampu menjadi media deradikalisme. Pengasuhan dengan gaya demokratis yang dimaksud dilakukan orang tua dengan kontrol serta kehangatan yang tinggi. Orang tua mengarahkan aktivitas anak, memberikan dorongan, mengapresiasi tingkah laku anak dan memberikan bimbingan. Anak diberikan kebebasan untuk mengurus dirinya sendiri, tetapi di sisi lain juga ditekankan harus disiplin sesuai dengan kesepakatan yang telah dibuat bersama (Daeng Pawero, 2018). Peraturan kedisiplinan diterapkan oleh orang tua, setelah sebelumnya diberikan penjelasanpenjelasan dan orang tua tidak otoriter dengan memaksa dalam pengambilan keputusan yang mereka buat dalam rapat keluarga. Untuk menghindari hal-hal yang tidak diinginkan yang kemungkinan dilakukan oleh anak, maka orang tua tetap melakukan pengawasan dan kontrol kepada anak. Ketika sang anak melakukan kesalahan, orang tua menegur dengan cara memberikan penjelasan yang baik untuk memperbaikinya tanpa melakukan pengekangan terhadap anak. Bahkan dianjurkan dalam agama untuk sedikit menggunakan hukuman dalam bentuk sanksi apabila anak melakukan kesalahan yang fatal.

Orang tua yang mempraktikkan jenis pengasuhan tersebut menyadari kewajibannya sebagai orang dewasa yang bertugas untuk mendidik dan mengayomi anak dengan mempertimbangkan sifat dasar anak demi membangun kualitas. Dalam keluarga, komunikasi merupakan kunci dari keseluruhan aspek yang seringkali dipermasalahkan. Ketika orang tua mampu menghindar dari hal-hal yang intoleran, maka secara tidak langsung anak akan belajar untuk menghargai perbedaan pendapat dan cenderung demokratis dalam bersikap dan menghindari dari pola pikir yang radikal, kasar dan memaksakan kehendak.

Terkait masalah radikalisme, sebuah hal yang penting untuk dilakukan oleh para tokoh agama, mulai dari ulama, guru agama di sekolah, kiai di pondok pesantren, dan dosen agama di perguruan tinggi, adalah menjelaskan tentang pengertian konsep jihad yang sebenarnya, terutama di lingkungan keluarga yang 
merupakan lembaga pendidikan informal pertama bagi anak-anak. Hal tersebut dikarenakan teori-teori tentang jihadlah yang selama ini yang merupakan konsep dasar dalam mengeratkan urat-urat radikalisme di Indonesia. Oleh karena itu melalui pendidikan agama Islam khususnya tentang fiqhi jihad dalam keluarga yang merupakan turunan dari bidang pendidikan aqidah dalam agama Islam merupakan pilar-pilar penyangga sikap nasionalisme dalam diri seseorang.

Sebagai sebuah doktrin agama, konsep jihad adalah sarana doktrinalisasi yang digadang-gadang berfungsi sebagai alat perjuangan agama dalam menjawab tantangan zaman. Jihad bukan produk otoritas individu atau penafsiran organisasi tertentu, melainkan produk yang dihasilkan dari berbagai individu, dan ditafsirkan dan diterapkan dalam prinsip-prinsip hidup dalam konteks khusus secara historis dan politis. Oleh karena itu, sebagai umat Islam yang ingin memahami konsep jihad dalam artian yang sebenarnya, maka kita harus membaca dan memahami ayat-ayat al-Qur'an secara historis dan seksama. Contohnya, mengkaji secara mendalam ayat al-Qur'an yang membahas tentang jihad seperti dalam Q.S. al-Ankabut/29: 69 yang artinya: "Dan mereka yang berjuang di jalan Kami, dan sesungguhnya Tuhan bersama mereka yang berbuat kebaikan."

Isi kandungan ayat tersebut menekankan konsep jihad sebagai perjuangan yang inhern melalui kesulitan dan kerumitan untuk mewujudkan kehidupan yang lebih baik. Jihad diartikan sebagai perjuangan melawan hawa nafsu yang ada di dalam diri sendiri dalam rangka mencapai keutamaan hidup, kemuliaan, kemakmuran, kesejahteraan baik secara ekonomi, politik dan sosial maupun budaya. Konsep jihad dalam Islam sebenarnya sangat tidak identik dengan radikalisme atau bahkan terorisme. Distorsi pemaknaan kata jihad yang seringkali dikonotasikan dengan kata-kata perang, peperangan dan berbagai macam derivasinya, seperti istilah qatala dan qital. Misalnya dalam Q.S. al-Hajj/22: 30-40, yang artinya: "Telah diizinkan berperang kepada mereka yang diperangi, oleh karena mereka sesungguhnya dianiaya, dan sesungguhnya Allah Maha berkuasa menolong mereka. Yaitu, orang-orang yang diusir keluar dari kampungnya dengan tidak ada sesuatu alasan yang patut, kecuali mereka berkata: "Tuhan kami adalah Allah". Ayat ini merupakan ayat yang pertama kali turun terkait dengan doktrin peperangan dan kekerasan dalam Islam.

Ayat tersebut telah ditafsirkan oleh seorang pakar sejarah bernama Ahmad Syalabi, seorang Profesor sejarah dari Universitas Kairo Mesir, dengan menyatakan bahwa barangsiapa yang hendak mendalami ayat tersebut maka dia akan melihat 
bahwa Islam sebenarnya tidak menginginkan peperangan. Menurut Syalabi, kata peperangan dalam ayat tersebut hanya sebatas pemberian izin bagi mereka yang dizhalimi dengan kata-kata "bi annahum-dzulimu" (karena sesungguhnya mereka dianiaya). Oleh karena itu sewaktu ayat ini diturunkan, beberapa kaum Muslimin sahabat Nabi belum cukup yakin dengan ayat ini untuk dijadikan alasan untuk melakukan peperangan (Syalabi, 2014).

Pemahaman yang salah tentang pemaknaan kata jihad sebenarnya bersumber dari kesalahan-kesalahan penafsiran ayat-ayat tentang jihad, yang dijadikan sebagai alat pembenaran oleh mereka yang beraliran garis keras (kelompok radikal dan fundamentalis) dalam Islam dalam melakukan berbagai wujud ekspresi radikalisme dengan memakai simbol agama. Sebagaimana pendapat al-Qardawi bahwa faktor utama munculnya sikap radikal dalam praktik beragama adalah kurangnya pemahaman yang benar dan kajian yang mendalam atas esensi ajaran agama Islam. Dalam bahasa sederhananya, Islam hanya dipahami secara dangkal dan parsial.

Pada kelompok yang beraliran radikal dan fundamental, Islam tidak hanya dipandang sebagai alternatif ideologis, tetapi merupakan kewajiban teologis dan praktik yang wajib dilakukan secara bersamaan. Selain mengacu pada akar teologis, kelompok tersebut juga menggunakan instrumen kata "jihad", yang diartikan sama dengan kata "perang". Konsep tentang jihad ini, seringkali memperoleh legitimasi dari kaum Islam fundamentalis dan radikal untuk melakukan aksi teror, sebagaimana yang marak terjadi di berbagai wilayah di dunia, termasuk Indonesia.

Sebagaimana telah diungkapkan panjang lebar diatas bahwa jalan yang terbaik ke depan untuk mengusung deradikalisasi adalah dengan membangun deradikalisasi agama melalui lembaga pendidikan, khususnya pada lembaga pendidikan pertama yang dienyam oleh seorang anak. Kiranya sangat diperlukan gerakan sosialisasi dalam bentuk penyuluhan tentang pendidikan agama Islam yang moderat atau lebih khusus tentang konsep jihad yang sebenarnya dalam masyarakat sebagai pengetahuan dasar agar memiliki bekal untuk mengajarkannya secara praktis dalam didikan dalam rumah tangga sebagai sikap dan tindakan anti radikalisasi agama. 


\section{Simpulan}

Berdasarkan uraian pada pembahasan dapat disimpulkan isi tulisan ini sebagai berikut:

Proses penanggulangan paham radikalisme (deradikalisasi) agama bukanlah pekerjaan yang hanya merupakan kewajiban pihak pemerintah, para guru-guru, maupun dosen yang mengajar pada perguruan tinggi, melainkan juga merupakan tugas para orang tua dalam memberikan pendidikan awal dalam tumbuh kembang pemikiran dan pemahaman seorang anak khususnya pendidikan agama Islam. Seorang anak yang tumbuh dalam didikan orang tua yang senantiasa menanamkan nilai-nilai moderasi dalam beragama, meneladankan sikap-sikap toleran dan sejak dini mengajarkan tentang konsep jihad yang tidak diidentikkan dengan kata perang dan kekerasan. Hal ini sangat penting untuk digalakkan mengingat sedang merebaknya kasus-kasus yang memakan korban dari aksi terorisme yang merupakan konsekuensi logis dari sebuah paham yang radikal.

\section{Referensi}

Daeng Pawero, A. M. V. (2018). Analisis Kritis Kebijakan Kurikulum Antara KBK, KTSP, dan K-13. Jurnal Ilmiah Iqra', 12(1), 42. https://doi.org/10.30984/jii.v12i1.889

Daradjat, Z. (2014). Ilmu Pendidikan Islam. Bumi Aksara.

Darmadji. (2013). Tafsir al-Qur'an Tentang Teori Pendidikan Islam: Perspektif Pendidikan Islam di Indonesia. Hermeneutik Jurnal Tafsir Hadits, 9(1), 223-244.

Golose, P. R. (2009). Deradikalisasi Terorisme, Humanis, Soul Approach dan Menyentuh Akar Rumput. YPTK.

Mahmud, \& Dkk. (2013). Pendidikan Agama Islam dalam Keluarga. Akademia Permata.

Martha, D. (2002). Psychology of Religion. Oxford.

Marwan, M., \& P, J. (2019). Kamus Hukum. Reality Publishe.

Nuhrison, M. N. (2009). Faktor-Faktor Penyebab Munculnya Paham/Gerakan Islam Radikal di Indonesia. Harmoni Jurnal Multikultural \& Multireligius, 8(2).

Qadir, Z. (2015). Radikalisme Agama di Indonesia. Pustaka Pelajar.

Salim, A. (2017a). Paradigma Kritis-Konstruktif:ljtihad Pengembangan Paradigma Pendidikan Islam Muhammadiyah dan Nahdatul Ulama. Journal of Islamic Education Policy. https://doi.org/10.30984/j.v2i2.695 
Salim, A. (2017b). Wacana Posmodernisme dalam Pemikiran Pendidikan Islam. Journal of Islamic Education Policy. https://doi.org/10.30984/j.v2i1.688

Syalabi, A. (2014). Sejarah dan Kebudayaan Islam. Pustaka al-Husna.

Wahab, A. J. (2019). Islam Radikal dan Moderat; Diskursus dan Kontestasi Varian Islam Indonesia. PT Elex Media Komputindo.

Wahid, A., \& Dkk. (2010). Islam Nir Kekerasan. Lkis. 